\section{Vapaan tahdon matka vaikeuksien kautta voittoon}

Visala, Aku (2018). Vapaan tahdon filosofia. Gaudeamus. 310 sivua.

KIRJAILIJA ALDOUS HUXLEY jakaa Uljaassa undessa maailmassa (1932) tulevaisuuden ihmiskunnan alfa-, beta- ja epsilon-luokkiin. Tyytyväisyys vallitsee, kun jokainen saa tehdä sitä, mitä osaa ja mistä on kiinnostunut. Akatemiatutkija Aku Visalan mukaan uuden uljaan maailman asukit täyttävät pintavapauksien kriteerit voidessaan tehdä, mitä haluavat. He pystyvät arvioimaan tekojensa perusteita ja ohjaamaan tekojaan näiden perusteiden mukaan. Sen sijaan asukkaat eivät toteuta syvävapautta, koska he eivät ole autonomisia eivätkä voi vaikuttaa siihen, miten heidän päämääränsä ja luonteensa syntyvät.

Pinta- ja syvävapauden sukulaiskäsitteinä Visala erottaa pelivaravapauden ja lähdevapauden. Vapaat teot ovat kiinni ihmisestä itsestään, mikä edellyttää myös kykyä tehdä toisin. Lisäksi toimijan on lisäksi kyettävä vaikuttamaan tekojensa syihin, olemaan tekojensa lähde tavalla, jota edeltävät syyt eivät määrää. Kuulostaa vaateliaalta, kuka voi varmasti väittää toimivansa useimmiten näin?

\section{DETERMINISMIN JA VAPAAN TAHDON YHTEENSOPIVUUS}

Varsin suuren osan kirjasta Visala käsittelee niin sanottua yhteensopivuusongelmaa: miten voi sovittaa yhteen determinismin ja vapaan tahdon?

Huomattava osa vapaata tahtoa pohtivia filosofeja jaotellaan kirjassa ensinnäkin niihin, joista ihmisen vapaa tahto sopii yhteen luonnon determinismin kanssa, ja toiseksi niihin, joiden mielestä näin ei ole, jolloin vapaata tahtoa ei voi olla. Kummassakin tapauksessa determinismi on annettu lähtökohta. Determinismioletus saa siten teoksessa suuren painoarvon, vaikka Visala toteaa, että fysiikassa kysymys determinismistä on sadan viime vuoden ajan ollut kaikkea muuta kuin yksiselitteinen.

Muunkinlaisia näkemyksiä esitellään, muun muassa libertarismi, joka korostaa indeterminismiä eli satunnaisuutta. Vapaan tahdon kannalta joudutaan kuitenkin paradoksiin: mitä enemmän painotetaan indeterminismiä, sitä enemmän myös psykologiset prosessit voi nähdä sattumanvaraisina, ja tekojen voi katsoa syntyvän vähemmän henkilöstä itsestään.

Libertarismi ei ole lainkaan niin harmiton suuntaus kuin millaisena se kirjassa esitetään. Jotkut sen kannattajat ovat kursailematta soveltaneet filosofiaansa laajasti yhteiskuntaan ja päätyneet mitä taantumuksellisimpiin näkemyksiin. Jokainenhan sen tietää, että

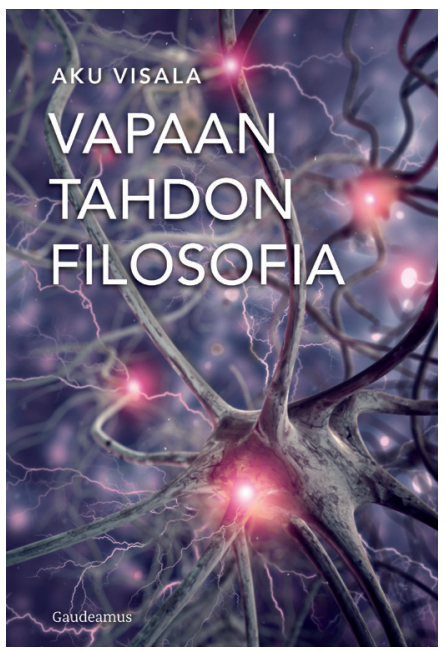

kun kerran tahto on vapaa, sairaus, köyhyys tai työttömyys ovat vain itsestä kiinni. Kuulostaako tutulta?

\section{OHJAAVA MINUUS PELASTAA} VAPAAN TAHDON

Monet tutkijat ovat tehneet pitkälle meneviä tulkintoja neurotieteiden tutkimustuloksista. Koska minää ei empiirisesti löydy aivoista sen enempää kuin sieluakaan, skeptikot haluavat tuomita minän esitieteelliseksi kategoriaksi. 'Minä' on vain mielentilojen eli aivotilojen kimppu, jolla ei voi olla mitään aivoistani ja mielentiloistani riippumatonta päätösvaltaa.

Visala liittää vapaan tahdon ohjaavaan minään. Kuljettuaan kirjassa pitkään tummissa laaksoissa vapaa tahto saa vielä mahdollisuuden päätösluvussa. Erotetaan kolme näkemystä: 1) Minä olen biologinen organismi; 2) Minä olen mielentilojen joukko; 3) Minä olen jotain, jolle mielentilat kuuluvat (s. 245). 
Tätä jotain Visala kutsuu 'ohjaavaksi minuudeksi'. Päätöksiä ei aiheuta mielentilojen joukko vaan toimija, minä. Kognitio- ja neurotieteissä tällaiselle oliolle ei ole paikkaa, mutta jos aivot ymmärretään itseohjautuvaksi, monimutkaiseksi järjestelmäksi, ohjaavan minuuden uskottavuus lisääntyy.

Itseorganisoituvat järjestelmät, kuten kala- ja lintuparvet, synnyttävät järjestystä ikään kuin alhaalta ylöspäin. Sitä vastoin itseohjautuvissa järjestelmissä on keskus, joka käsittelee tietoa järjestelmän muista osista ja säätelee niiden toimintaa. Toimija voidaan siten nähdä itseohjautuvana järjestelmänä. Vapaan tahdon kunnianpalautusta auttaa etäisyyden otto reduktionismiin eli mielentilojen palauttamiseen aivotiloiksi ja fysiikaksi. Vaikka monet ihmisen toiminnot ovat automatisoituneet, teoiksi kutsuttavat käyttäytymisen muodot ovat Visalan mukaan tulosta toimijuudesta ja itseohjautuvuudesta.

Visala hakee siten tukea myös systeemiajattelusta, jota kirjassa voisi laajemminkin avata. Viime vuosikymmeninä systeemitutkijat ovat keskustelleet siitä, voiko ihmisyksilöä lainkaan pitää systeeminä. Visala vastaa myönteisesti. Monet systeemitutkijat näyttävät kuitenkin kallistuvan sille kannalle, että ihmisyksilö voidaan nähdä erilaisten ja eri tieteenalojen tutkimien systeemien "läpivirtauskohtana”.

\section{VAPAUS VAILLA KONTEKSTIA}

Sisällökäs ja monia näköaloja avaava esitys vapaan tahdon filosofiasta avaa samalla länsimaista ajattelua. Visala tukeutuu pääosin anglosaksiseen analyyttiseen filosofiaan, joka arvostaa loogisesti yhteensopivia abstrakteja väitteitä enemmän kuin kontekstuaalisuutta. Vapaa tahto näyttäytyy teoksessa useimmiten yksilön valintoina ilman toista, historiaa, luokkaasemaa, uskontoa, etnisyyttä ja sukupuolta. Tällöin tahdon vapaus on sama niin ketunmetsästystä harrastavalla lordilla kuin kumiveneellä Välimerta ylittävällä afrikkalaisella.

Visala kyllä pehmentää lopussa otettaan ja sivuaa etiikkaa, kulttuurisia tekijöitä, viisautta ja ihmisen perustavaa sosiaalisuutta, mutta yhteiskunnallinen särmä on rajattu pois. Ei eroteta liberalismin korostamaa negatiivista vapautta eli vapautta jostakin, ja vapautta johonkin, itsetoteutuksen mahdollistavaa vapautta.

Kontingenssin alueen - ei väistämätöntä, mutta ei mahdotontakaan - kartoittaminen toiminnan mahdollisuuksien vyöhykkeenä olisi auttanut tuomaan kontekstia tahdonvapauden kysymyksiin. Kontingenssiajattelua esiin tuoneet tukijat korostavat, että epävarmuudessa suunnistettaessa lähestymistapa voi auttaa lupaavuuden löytymistä ei-mahdottoman ja ei-väistämättömän alueella.

Keskustelua kaipaisi väite, että rikosoikeudellinen vastuu on ikään kuin institutionalisoitu versio moraalisista käytännöistä (s. 36). Kuitenkin antiikin filosofi Aristoteles totesi, että sääntöjä tarvitaan pahan torjumiseksi, hyveitä hyvän saavuttamiseksi. Lait ja moraali olisivat siten eri ulottuvuudella, vaikka voi toivoa, etteivät ne ole keskenään pahasti ristiriidassa.

\section{JUSSI ONNISMAA}

FT, dosentti, työnohjaajakouluttaja Werka kehitys Oy 